\title{
A study on the timing of HIV repeat test: A case study of Mary Immaculate VCT Center, Nairobi, Kenya
}

\section{Otieno Okech (Victor Otieno Okech)1, V. Wanjala Namulanda Victor Wanjala Namulanda) ${ }^{2,3}$, D. Kimuli (Daria Kimuli)2}

${ }^{1}$ Comenius University in Bratislava, Faculty of Education, Department Original Article of Social Work, Slovakia.

${ }^{2}$ St. Elizabeth College of Health and Social Sciences, Bratislava, Slovakia.

${ }^{3}$ Mary Immaculate VCT Center, Nairobi, Kenya.

\section{E-mail address:}

okech1@uniba.sk

\section{Reprint address:}

Victor Otieno Okech

Department of Social Work

Comenius University in Bratislava

Soltesovej 4

81334 Bratislava

Slovakia

Source: Clinical Social Work and Health Intervention

Volume: 12

Issue: 2 Pages: $57-62$

Cited references: 19

\section{Reviewers:}

Pawel S. Czarnecki

Rector of the Warsaw Management University, PL

Roberto Cauda

Institute of Infectious Diseases, Catholic University of the Sacred Heart, Rome, IT

\section{Keywords:}

HIV Inter-test Interval. HIV Repeat-testing. HIV Testing,HIV Re-testing.

\section{Publisher:}

International Society of Applied Preventive Medicine i-gap

CSWHI 2021; 12(2): 57 -62; DOI: 10.22359/cswhi_12_2_11 (C) Clinical Social Work and Health Intervention

\section{Abstract:}

Population testing, especially those at risk, plays an important role in preventing and managing the HIV pandemic. It helps practitioners in identifying individuals who need to be counseled on behavior change as well as those who need to be enrolled in HIV care and treatment programs. Further still, policy makers also use outcomes of such tests in determining whether their strategies are bearing fruits or not. In this study, we sought to determine the time interval within which sexually active individuals seek HIV repeat tests in relation to their gender and marital statuses.

We observed that majority of the respondents $(39.8 \%, \mathrm{n}=47)$ 
sought HIV repeat test within a period of 7-12 months, which we considered as short interval that leads to early diagnosis. We also observed a section of the respondents were also seeking HIV repeat test after a period that exceeded 13 months. We considered the latter as long interval that leads to late diagnosis of HIV. We further observed that, a majority of the respondents who were either married or had never been married before, sought HIV repeat tests within a short interval compared to those who were either divorced or widowed.

We concluded that most widowed and divorced respondents were more likely to receive late diagnosis of HIV than those who were either married or had never been married before. Most studies have indicated that people who are unaware of their HIV status carry a higher risk of infecting others.

\section{Introduction}

HIV testing is an essential component of HIV prevention and management strategy. Its results help practitioners make informed decisions when enrolling patients into the HIV care and treatment programs. Equally, outcomes of such testing also help policy makers in determining effectiveness of their HIV prevention strategies, such as proportions of the diagnosed and undiagnosed populations (Subramanian, et al., 2018). Undiagnosed populations, especially those that comprise individuals who have been infected but are unaware, remains a major challenge in the fight against HIV. According to Marks, Crepaz, \& Janssen (2006), approximately 50-70\% of people who newly get infected with HIV, acquire it from people who were unaware of their serostatus. Thus, HIV testing, especially a repeat test, plays an important role in nipping at its bud, the spread of HIV. Scientific studies have had mixed outcomes on the effectiveness of HIV repeat tests in reducing if not preventing the spread of this infectious virus. Some studies have pointed out that HIV repeat tests lead to irresponsible sexual behaviors, especially among those who return HIV negative results (Hoenigl, et al., 2015) while others have shown that HIV repeat tests play significant roles in suppressing its spread, through behavior change.

Early identification of HIV infection has been associated with benefits such as timed treatment that ensures maximum gains and reduction in HIV transmission among populations at risk (Šebestová \& Plavčan, 2018; Tuma \& Ondrusova; Kopinec, 2015; Castilla, et al., 2002; Shahum, et al., 2017). The optimal time for initiating HIV treatment is still an ongoing debate with most guidelines recommending that it should be initiated before the symptomatic phase. Though, this is the case, a good proportion of individuals get enrolled into the HIV care and treatment programs when they have reached the symptomatic phase of the disease due to late diagnosis (Girardi, et al., 2000). According to Fisher (2008), late diagnosis of HIV, defined as $\mathrm{CD}^{+}{ }^{+} \mathrm{T}$ cell count less than 200 cells $/ \mathrm{mm}^{3}$ or with AIDS-defining illnesses, has been associated with increased mortality rate among patients who test positive for the virus. In addition, in developed countries heterosexual people tend to be diagnosed late for HIV compared to men who have sex with other men and those who use intravenous drugs.

Our aim in this study was to determine the time interval within which sexually active individuals seek HIV repeat tests in relation to their gender and marital statuses. This study was carried-out, between 2019 and 2020 at the Mary Immaculate Voluntary Counseling and Testing (VCT) Center, in Nairobi-Kenya.

\section{Methods}

\section{Study participants}

This study enrolled a total of 118 participants, aged between 18 and 64 years, who had sought HIV repeat-test services at the Mary Immaculate Voluntary Counseling and Testing (VCT) Center in Nairobi, Kenya.

\section{Study design and data collection}

This is study examined the behaviors of respondents in relation to HIV repeat where only 
those who were seeking HIV repeat tests were enrolled. A standardized questionnaire that masked identity of the respondents was used in collecting data. Respondents who could not fill in the questionnaires on their own for various reasons were assisted by research assistants. The questionnaire collected the following information from the respondents: i) sociodemographic information; ii) reason for the seeking the test; iii) HIV tests interval i.e., date last tested before the current one. Informed consent was also obtained from all the respondents.

\section{Statistical analysis}

This study employed two levels of analysis. The fist level comprised of analyzing demographic data using descriptive statistical procedures. The $2^{\text {nd }}$ level involved the use of Pearson's chi square $\left(X^{2}\right)$ to analyze the HIV testing intervals. Cross tabulation was used in comparing HIV test intervals with marital status and gender of the respondents. SPSS version 23 was used in conducting the analysis.
Table 1: HIV testing interval and reasons for HIV tests

\section{Results: b) HIV Repeat Tests}

\begin{tabular}{lc}
\hline HIV repeat & $\begin{array}{c}\text { Total number } \\
\text { of respondents } \\
(\mathbf{n}=118)\end{array}$ \\
tests & $\begin{array}{c}\mathbf{n}(\%) \text { of the } \\
\text { respondents }\end{array}$ \\
\hline HIV Tests & \\
Interval & $29(24.6 \%)$ \\
$1-6$ Months & $47(39.8 \%)$ \\
$7-12$ Months & $10(8.5 \%)$ \\
$13-18$ Months & $13(11.0 \%)$ \\
$19-24$ Months & $19(16.1 \%)$ \\
$\geq 25$ Months &
\end{tabular}

\section{Discussions}

In this study we sought to determine the time interval within which sexually active individuals seek HIV repeat tests in relation to their gender and marital statuses. We defined HIV testing interval as the length of time, in months, which in-

Table 2: Cross tabulation of gender and HIV testing intervals

\begin{tabular}{|l|c|c|c|c|c|c|}
\hline \multirow{3}{*}{ Gender } & \multicolumn{7}{|c|}{ HIV Testing Intervals (Months) } \\
\cline { 2 - 7 } & $\begin{array}{c}\mathbf{1 - 6} \\
\text { months } \\
\mathbf{n}(\%)\end{array}$ & $\begin{array}{c}\mathbf{7 - 1 2} \\
\text { months } \\
\mathbf{n}(\%)\end{array}$ & $\begin{array}{c}\mathbf{1 3 - 1 8} \\
\text { months } \\
\mathbf{n}(\%)\end{array}$ & $\begin{array}{c}\mathbf{1 9 - 2 4} \\
\text { months } \\
\mathbf{n}(\%)\end{array}$ & $\begin{array}{c}\mathbf{2 2 5} \\
\text { months } \\
\mathbf{n}(\%)\end{array}$ & Totals \\
\hline Male & $10(32.3 \%)$ & $10(32.3 \%)$ & $4(12.9 \%)$ & $3(9.7 \%)$ & $4(12.9 \%)$ & $31(100 \%)$ \\
\hline Female & $19(21.8 \%)$ & $37(42.5 \%)$ & $6(6.9 \%)$ & $10(11.5 \%)$ & $15(17.2 \%)$ & $87(100 \%)$ \\
\hline Total & $29(24.6 \%)$ & $47(39.8 \%)$ & $10(8.5 \%)$ & $13(11.0 \%)$ & $19(16.1 \%)$ & $118(100 \%)$ \\
\hline $\mathrm{X}^{2}=\mathbf{0 . 5 7 1}$ & & & & & \\
\hline
\end{tabular}

Table 3: Cross tabulation of marital and HIV testing intervals

\begin{tabular}{|l|c|c|c|c|c|c|}
\hline \multirow{3}{*}{$\begin{array}{l}\text { Marita } \\
\text { Status }\end{array}$} & $\begin{array}{c}\mathbf{1 - 6} \\
\text { months } \\
\mathbf{n}(\%)\end{array}$ & $\begin{array}{c}\mathbf{7 - 1 2} \\
\text { months } \\
\mathbf{n}(\%)\end{array}$ & $\begin{array}{c}\mathbf{1 3 - 1 8} \\
\text { months } \\
\mathbf{n}(\%)\end{array}$ & $\begin{array}{c}\mathbf{1 9 - 2 4} \\
\text { months } \\
\mathbf{n}(\%)\end{array}$ & $\begin{array}{c}\mathbf{2 2 5} \\
\text { months } \\
\mathbf{n}(\%)\end{array}$ & Totals \\
\hline Unmarried & $10(26.3 \%)$ & $15(39.5 \%)$ & $2(5.3 \%)$ & $6(15.8 \%)$ & $5(13.2)$ & $38(100 \%)$ \\
\hline Married & $14(24.6)$ & $25(43.9 \%)$ & $5(8.8 \%)$ & $4(7.0 \%)$ & $9(15.8 \%)$ & $57(100 \%)$ \\
\hline Divorced & $5(25.0 \%)$ & $6(30.0 \%)$ & $3(15.0 \%)$ & $3(15.0 \%)$ & $3(15.0 \%)$ & $20(100 \%)$ \\
\hline Widow/ed & $0(0.0 \%)$ & $1(33.3 \%)$ & $0(0.0 \%)$ & $0(0.0 \%)$ & $2(66.7 \%)$ & $3(100 \%)$ \\
\hline Total & $29(24.6 \%)$ & $47(39.8)$ & $10(8.5 \%)$ & $13(11.0 \%)$ & $19(16.1)$ & $118(100 \%)$ \\
\hline$X^{2}=\mathbf{0 . 5 7 4}$ & \multicolumn{7}{|c|}{} & & \\
\hline
\end{tabular}


dividuals take between two tests. In comparing the HIV testing intervals with gender, we observed that $64.4 \%(n=76)$ of the respondents took HIV repeat-test within a period of 12 months which we considered as a short interval that leads to early diagnosis; while $35.6 \%(n=42)$ took HIV repeat-test after a period that exceeded 13 months which we considered as long interval which on the other hand leads to late diagnosis of HIV. Late diagnosis of HIV has been associated with risk of HIV related morbidities and mortalities; increased direct cost of the disease management (such cost of drugs, laboratory tests, outpatient care and home care) and increased risk of HIV transmission (Fisher, 2008; Krentz, et al., 2004; Horvathiva, et al., 2011). Studies have also pointed out factors that lead to late diagnosis include denial of HIV positive status; poor selfcare; communication breakdown between healthcare workers and their patients; and barriers associated with accessibility to the test sites such as cost and distance from health facilities (Krentz, et al., 2004; Fisher, 2008; Sharma, et al., 2018). In this study we observed that very few men $26.3 \%(n=31)$ compared to women $73.7 \%$ $(\mathrm{n}=87)$ were turning up for HIV repeat tests. Though in this study we did not examine factors that hinder them from seeking HIV repeat tests, we suspect that work-related commitments could be one of the factors that keeps them away from seeking HIV repeat tests. Most VCTs, in Kenya, operate only during weekdays, from 8 am to 5 $\mathrm{pm}$. This makes it hard for those who are employed to access the VCT services.

We also examined effects of marital status on the length of time individuals take to seek HIV repeat tests. We observed that more married respondents $48.3 \%(n=57)$ than widowed respondents $2.5 \%(n=3)$ sought HIV repeat-tests. This is because married respondents encounter more pull and push factors associated with HIV repeat tests than their counterparts who are widowed (Neszméry, 2020). In Kenya, for instance, one of such pull and push factors is the inclusion of HIV test as part and parcel of antenatal care package. Thus, all pregnant women who attend antenatal care, in Kenya, at certain points get tested for HIV. In one study done by Nzioki, et al., (2015) in Mwingi, a district in Kenya, observed that a majority $(73.6 \%)$ of the women who attend Antenatal Clinics (ANC) are married compared to
$5.8 \%$ who are widowed. Their findings show that married women have higher chances of being tested for HIV than their counterparts who are widowed. We further observed that a majority of the widowed respondents $(66.7 \%, \mathrm{n}=2)$ sought HIV repeat tests after a period that exceeded 25 months compared to the majority of the married ones $(43.9 \%, \mathrm{n}=25)$ who get tested within a period of 7-12 months. We also observed that a widowed who took a repeat HIV test was a result of referral by health workers when they had gone to seek treatment for other medical conditions. Though widowed individuals rarely seek HIV repeat tests, a study done in Kenya and Malawi by Anand, et al., (2009), found that they were sexually active. This makes them part of the unaware population that could be contributing to the spread of HIV.

We also examined factors that motivated respondents to seek HIV repeat tests. We observed that most of them, $44.1 \%(n=52)$, took it as a 'routine' test for the purpose of either initiating new intimate relationships with their partners or modifying risky behaviors that could predispose them to contracting HIV. We further observed that $25.4 \%(n=30)$ of the respondents took the repeat test as result of being referred by healthcare professionals. This group comprised of respondents who had gone to the clinic specifically for treatment of other medical conditions such as tuberculosis but ended up being referred to the VCT for HIV test. We also noticed another group of respondents, $23.7 \%(\mathrm{n}=28)$, who were taking repeat tests for the purpose of confirming results of their previous HIV tests. This group was comprised of respondents who were living in denial over their HIV status. Psychological processes due to loss, in this case loss of health, and stigma associated with HIV are some of the factors that push people into denial (Mikolasova, et al., 2018; Li, Wong, et al., 2016; Krentz, et al., 2004). We also observed that only a small proportion of pregnant women $(6.8 \%, \mathrm{n}=8)$ who were seeking HIV repeat tests. This was because the VCT center where we did this research does not provide labor and maternity services to pregnant women making pregnant women to opt for repeat tests in other facilities when their due dates edges closer. In addition, some women also begin their antenatal care very late in their pregnancies, making it hard for them to attend HIV repeat tests. Most 
studies have documented the importance of HIV repeat tests in eliminating risks associated with transmission of the virus during pregnancy, labor and breastfeeding. In one study done in South Africa by Moodley, et al. (2009) on pregnant women, found that at least $3 \%(n=72)$ of 2,377 pregnant women who had tested negative in the first HIV test, returned positive results in their repeat tests.

\section{Conclusions}

We conclude that most respondents prefer to seek HIV repeat tests within 12 months while men and widowed individuals rarely seek repeat HIV tests. We recommend that VCT services should be availed over the weekend so those with busy schedule, during weekday, can also access them.

\section{References}

1. ANAND A, SHIRAISHI R W, BUNNELL R E, JACOBS K, SOLEHDIN N, ABDULQUADER A S, . . . DIAZ T (2009) Knowledge of HIV status, sexual risk behaviors and contraceptive need among people living with HIV in Kenya and Malawi. AIDS, 23(12), pp 1565-1573. doi:10.1097/QAD.0b013e32832cb10c.

2. CASTILLA J, SOBRINO P, LUIS D L, NOGUER I, GUERRA L, PARRAS F (2002) Late diagnosis of HIV infection in the era of highly active antiretroviral therapy: consequences for AIDS incidence. AIDS, 16(14), 1945-1951.

3. FISHER M (2008) Late diagnosis of HIV infection: major consequences and missed opportunities. Current Opinion in Infectious Diseases, 21(1), pp 1-3. doi:10.1097/QCO.0b013e3282f2d8fb.

4. GIRARDI E, SAMPAOLESI A, GENTILE M, NURRA G, IPPOLITO G (2000). Increasing Proportion of Late Diagnosis of HIV Infection Among Patients With AIDS in Italy Following Introduction of Combination Antiretroviral Therapy. J of Acquired Immune Deficiency Syndromes, 25(1), pp 7176.

5. HOENIGL M, ANDERSON M C, GREEN N, MEHTA R S, SMITH M D, LITTLE J S (2015) Repeat HIV-testing is associated with an increase in behavioral risk among men who have sex with men: a cohort study. BMC Medicine, 13(218), pp 1-10. doi:10.1186/ s12916-015-0458-5.

6. HORVATHOVA E, MACKINOVA M P, RUSNAKOVA V, DOKTOROV A, KRCMERY V, FIALA P, . . PHILIPPE M (2011) News in AIDS social work with HIV positive management and prevention. Clinical Social Work, 2(4), pp 49-60.

7. KOPINEC P (2015) Jaroslav Janos prison Governor, Corps of Prison and Court Guard, Slovak Republic. In M. H. Hurley, KD. Das, Trends in Corrections: Interviews with Corrections Leaders Around the World (pp. 3555). Boca Raton. CRC Press.

8. KRENTZ H, AULD M, GILL M (2004) The high cost of medical care for patients who present late $(C D 4<200$ cells/ $\mu L)$ with HIV infection. HIV Medicine, 5(2), pp 93-98. doi:10.1111/j.1468-1293.2004.00193.x.

9. LI A T W, WONG J P H, CAIN R, FUNG K P L (2016) Engaging African-Caribbean, Asian, and Latino community leaders to address HIV stigma in Toronto. International J of Migration, Health, and Social Care, 12(4), pp 288-300. doi:10.1108/IJMHSC-07-20140029

10. MARKS G, CREPAZ N, JANSSEN S R (2006) Estimating sexual transmission of $H I V$ from persons aware and unaware that they are infected with the virus in the USA. AIDS, 20(10), pp 1447-1450.

11. MIKOLASOVA G, SETA S, HOIN H, OTRUBOVA J, BENCA J, BARTKOVJAK M (2018) Improved Adherence to ART in Children-Orphans with AIDS Results in the Decreasing Occurrence of Tuberculosis. Clinical Social Work and Health Intervention, 9(4), pp 81-83. doi:10.22359/cswhi_9_4_14.

12. MOODLEY D, ESTERHUIZEN M T, PATHER T, CHETTY V, NGALEKA L (2009) High HIV incidence during pregnancy: compelling reason for repeat HIV testing. AIDS, 23(10), 1255-1259.

13. NESZMERY S (2020). Divorce as a cause of disruption of interpersonal relationships. World Social Work Day. VI (pp 162-179). Sladkovicovo: University Danubius.

14. NZIOKI M J, ONYANGO O R, OMBAKA H J (2015). Socio-Demographic Factors Influencing Maternal and Child Health Service 
Utilization in Mwingi; A Rural Semi-Arid District in Kenya. American Journal of Public Health Research, 3(1), pp 21-30. doi:10.12691/ajphr-3-1-4.

15. SEBESTOVA P, PLAVCAN P (2018) Multidisciplinary approach in addiction treatment. Review of Social Sciences and Humanities, 6(4), pp 1-12.

16. RADI F, BUDZELOVA K, OLAH M, MUSS C (2021) Late psychosocial consequencesfrom HIV to Covid. Clin Soc Work and Health Interv.12.2021.2.6-7. 10.22359/cswhi_12_2_15.

17. SHARMA M, SMITH J A, FARQUHAR C, YING R, CHERUTICH P, GOLDEN M, . . . BARNABAS R V (2018) Assisted partner notification services are cost-effective for decreasing HIV burden in western Kenya. AIDS, 32(2), pp 233-241.

18. SUBRAMANIAN S, BELOVICOVA M, VANSAC P, PALUN M, RADKOVA L, OTRUBOVA J (2018) Rehabilitation and Nursing Homes with Elderly and Homeless Population, Lessons not only for Physiotherapy but also for Epidemiology? Clinical Social Work and Health Intervention, 9(3), pp 64-66. doi:10.22359/cswhi_9_3_08.

19. TUMA J, ONDRUSOVA Z (n.d.) Assisting families at Risk of Poverty in the Context of Social Services. Clinical Social Work and Health Intervention, 9(2), pp 101-105. doi: 10.22359/cswhi_9_2_15. 